\title{
新設汎用境界層風洞の基本性能について \\ On the Performance of New Wind Tunnel
}

\begin{abstract}
SUMMARY
This paper describes the outlines and the performance of the new boundary layer type wind tunnel constructed at Sato Kogyo Engineering Research Center. It is the multi-purpose wind tunnel which can be used for many researches on the wind engineering. Considering that it will be used principally for the architectural design, it was designed to have a long test-section. And it has a large test-section, so the wind tunnel test for the large buildings can be conducted. Its maximum windspeed is above $30 \mathrm{~m} / \mathrm{s}$. This paper describes also the results of the simulation on the boundary layer flow using spires and roughness blocks.
\end{abstract}

\section{1.はじめに}

超高層建物の建設はますます增加し，また，余睱時間 の增加に伴い，種々のレジャー・イベント施設の大型 化も進んでいる。このような構造物の設計を行うには, その安全性や居住性に対して,より過酷な影䪪を及ぼす ようになる風に対する検討が欠かせないものになって きている。建物周辺への風の影䇾等を含めて, より合理 的な耐風設計を行うには, 自然風を再現できる風洞で模 型実験を行うことが, 現時点では最も有効で, かっ, 合 理的な手段である。

このような要求に答えるため、佐藤工業中央技術研究
所内に大型回流型境界層風洞が新設された。。本風洞は 平成 3 年秋に竣工し、諸調整、基本性能調查、風作りを 経て、平成 4 年春より稼働し始め、同年秋までに実物件 5 件についても風洞実験を実施してきている。 本報告は, 上記風洞の概要について記すものである。

\section{2. 風洞の概要および蓄成}

2. 1 設計方針

本風洞実験施設の計画に当たっては, 特に以下のよう

な点に考慮して、計画および設計を進めた。

風工学分野で行われる種々の風洞実験 (ビル風害実験、

$* 1$ 佐藤工業株式会社中央技術研究所、主席研究員

Research Head, Engineering Research Center, SATO KOGYO Co., Ltd.

* 2 佐藤工業株式会社中央技術研究所

Engineering Research Center, SATO KOGYO Co., Ltd.

*3 佐藤工業株式会社中央技術研究所

Engineering Research Center, SATO KOGYO Co., Ltd.

(绵稿受理: 1992 年 12 月 10 日) 


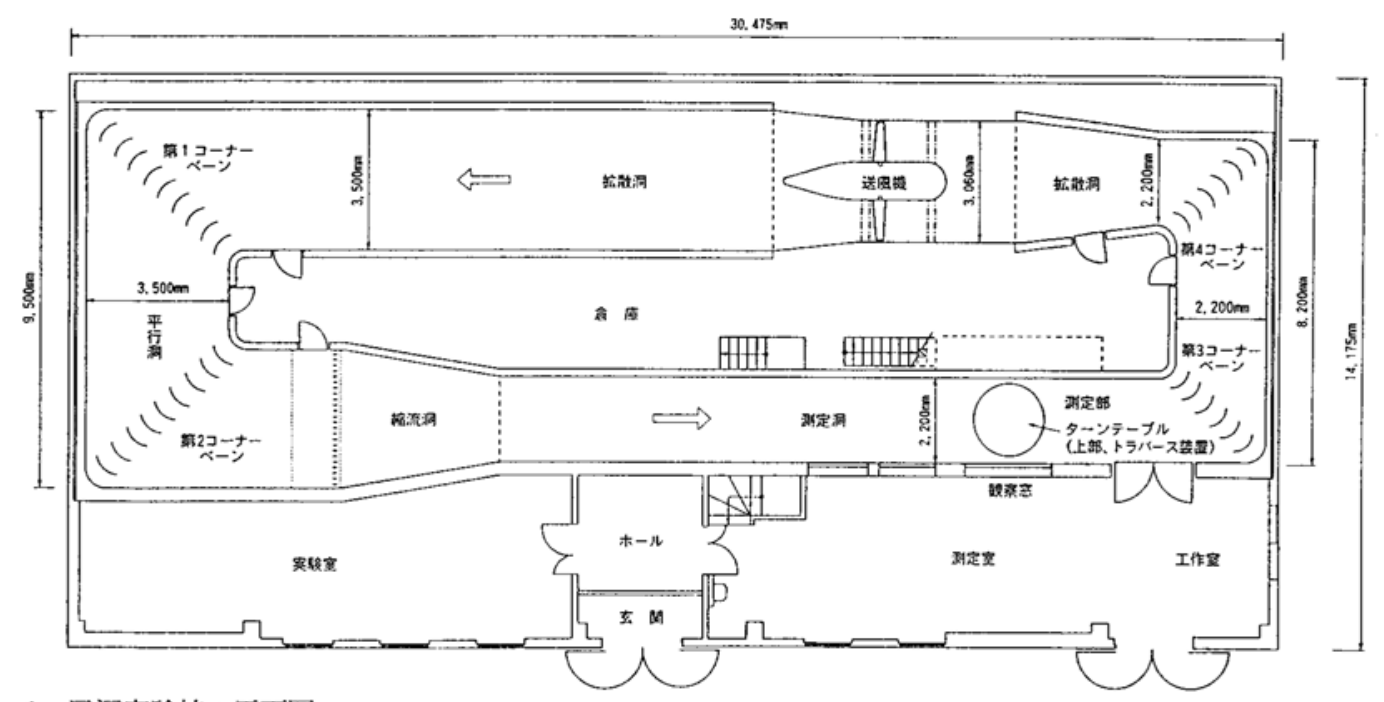

Fig. 1 風洞実験棟の平面図

(Plan of the wind tennel of Engineering Reserch Center, SATO KOGYO Co., Ltd.)

風圧実験、風力実験、振動実験、拡散実験、風力換気 実験等）に対応可能な汎用タイプとすること。

超高層建築物等の大規模建築物も、比較的、大きな縮 尺で実験が可能な大きさの測定部断面を有すること。た だし, 建設場所の敷地に限界があり,この限界内で, 所 定の性能を有しながら, 上記の要求をいかに満足させる かがポイントであった。

風洞の性能目標としては，ほとんどの場合に境界層風 洞として使用されることを考虑して, 風速の偏差および 乱れの強さを $1 \%$ 以下とすることとした。風洞風速は， 最大風速 $30 \mathrm{~m} / \mathrm{s}$ 目標とした。

また,トラバース装置の閉塞率を最小にすることを, その設計目標の一つとした。

また, 風洞胴体部に関しては, その風性を高めて, 壁面 等の振動が実験気流に影響しないようにすること, 外気 温に対する断熱性についても十分に配虑すること, を要

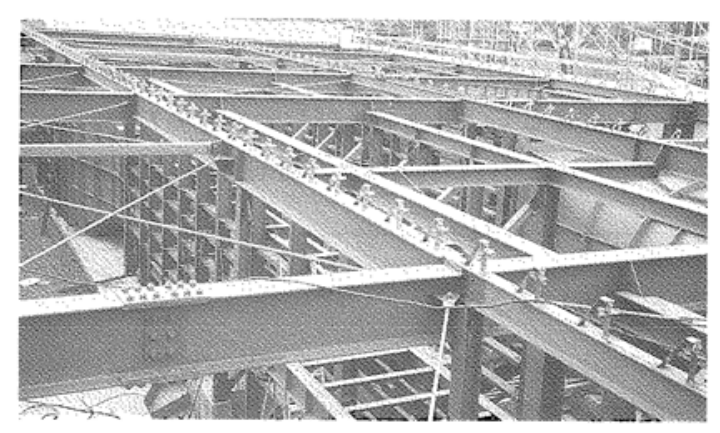

Photo. 1 風洞の鉄骨フレーム

(Steel frame of the wind tunnel)
求した。

\section{2 風洞実験棟建屋の概要}

風洞実験棟は, 鉄骨造平屋建であり, 外壁はALC版, 屋根は断熱材立て込みのダブル折板とした。風洞実験 棟の平面はFig. 1に示すとおりである。実験棟は風洞 を一体的に包含するように計画されており、柱割や梁 伏もこれを前提に決められた (Photo. 1 参照)。

\section{2 . 3 風洞の概要および諸元}

Fig. 1に示すとおり, 本風洞は回流型境界層風洞であ る。Table 1 に本風洞の諸元および仕様をまとめて示 した。測定部断面は幅2. $2 \mathrm{~m} \times$ 高さ $1.85 \mathrm{~m}$ (断面積 $4.07 \mathrm{~m}^{2}$ ) とした。

Table 1 風洞の諸元および概要仕様 (Outlines and performance of the wind tunnel)

\begin{tabular}{|c|c|}
\hline 㶡洞型式 & 回流型境界層風洞 \\
\hline 测 定 洞 寸法 & $\begin{array}{l}\text { 蝠 } 2.2 \mathrm{~m} \times \text { 高さ } 1.85 \mathrm{~m} \times \text { 長さ } 16.8 \mathrm{~m} \\
\text { (ターンテーブル中まで } 13.0 \mathrm{~m})\end{array}$ \\
\hline 縮流比 & 3.01 \\
\hline 测 定 部 風 速 & $\sim 31 \mathrm{~m} / \mathrm{s}(0.6 \mathrm{~m} / \mathrm{s}$ より速繶可㡅) \\
\hline 屈 & $7.500 \mathrm{~m}^{3} / \mathrm{min}$ \\
\hline 强速分布 & $\pm 1.0 \%$ 以下 (断面寸法の $80 \%$ 以内) \\
\hline 乱れの強さ & $0.7 \%$ 以下 (ターンテーフル中心) \\
\hline 送風 & 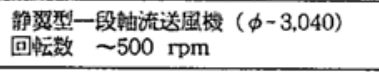 \\
\hline$E-g$ & 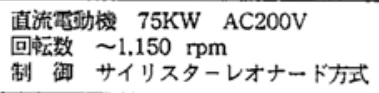 \\
\hline
\end{tabular}




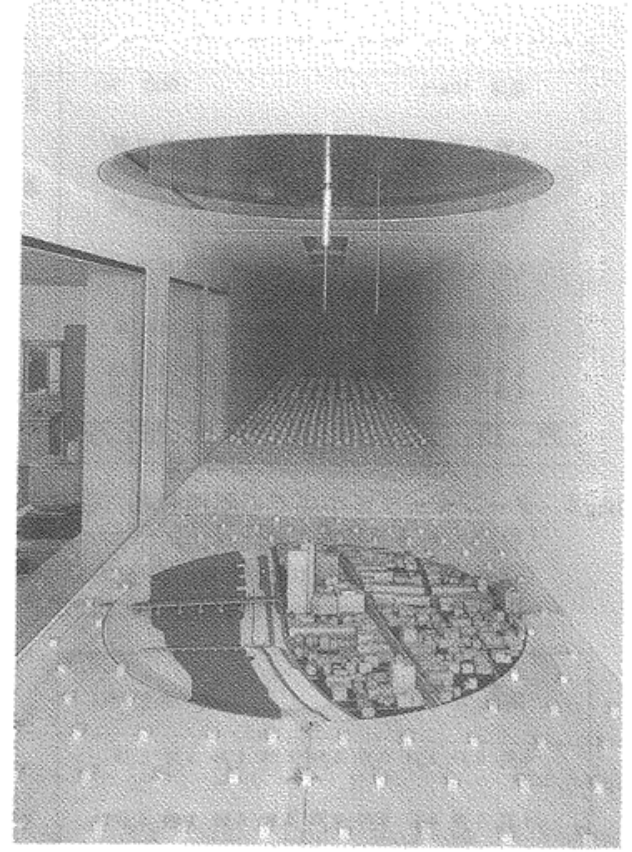

Photo. 2 測定部

(Working section)

風洞本体は，鋼製の工場製作部分を除き, 天井面・壁 面・床面とも鉄骨下地に厚さ $25 \mathrm{~mm}$ の合板貼りとしてい

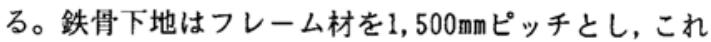

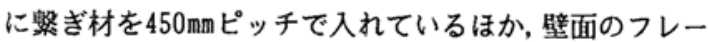
ム材を建物の棈造材と熟いでおり、また、天井面およ び床面のフレーム材を吊り材または方杖で補剛するこ とにより，十分な㑉性を確保するようにした（Photo.

Table 2 付帯装置の仕様

(Specification of the accessory equipments)

\begin{tabular}{|c|c|}
\hline 箈 & 仕 \\
\hline トラバース装速 & 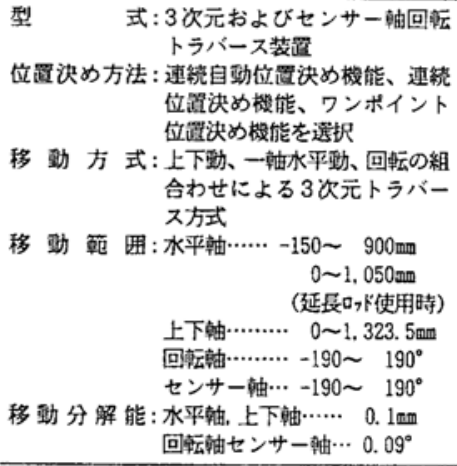 \\
\hline 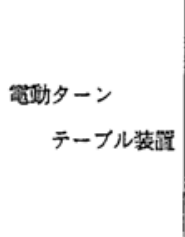 & 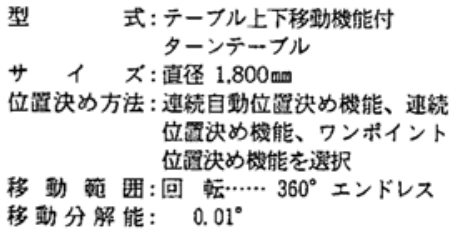 \\
\hline
\end{tabular}

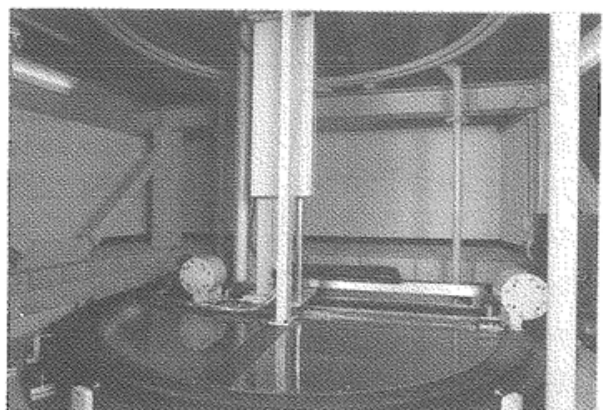

Photo. 3 3次元トラバース装置 (3-D Traverser)

1参照)。また, 建物外壁とは別に, 風洞本体の壁面を設 けて, 間に空気層を取ることによって, 断熱を図ってい る。Photo. 2 に測定部を示した。

\section{4 测定部付带設備の概要}

ターンテーブル装置および3次元トラバース装置の仕 様はTable 2 に示すとおりである。ターンテーブルの 直径は $1,800 \mathrm{~mm}$ である。3次元トラバース装置は, 上下動, 一軸水平動に回転動を組合わせた移動方式のものであ る (Photo. 3参照)。風路内に入るのは上下方向のシ ヤフトのみであり,トラバース装置による風洞の閉塞率 は最大でも1.6\%と極めて小さくすることができた。こ れらは制御用および計測用コンピュータの連脜によっ て自動運転・計測が可能である。

\section{3. 風洞の基本性能}

\section{1 整流装置の効果について}

整流装犆を設けない場合, 整流ネット(\#34)を1枚およ び2枚設置した場合のそれぞれについて, ターンテーブ ル中心での風速の乱れの強さの测定例をFig. 2 に示し た。整流装置を設けない場合には, 高風速になっても, 乱れの強さは1\%を上回った。整流ネットを1枚設置し

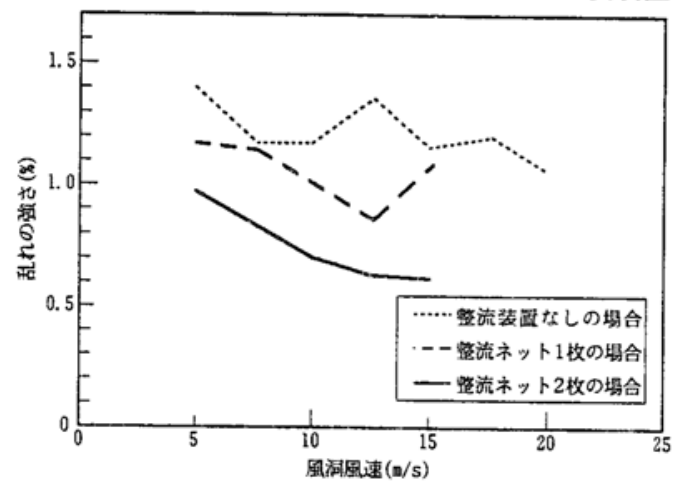

Fig. 2 乱れの強さ（ターンテーブル中央、高さ $\mathrm{z}=675 \mathrm{~mm}$ ) (Intensity of turbulence at the working section) 


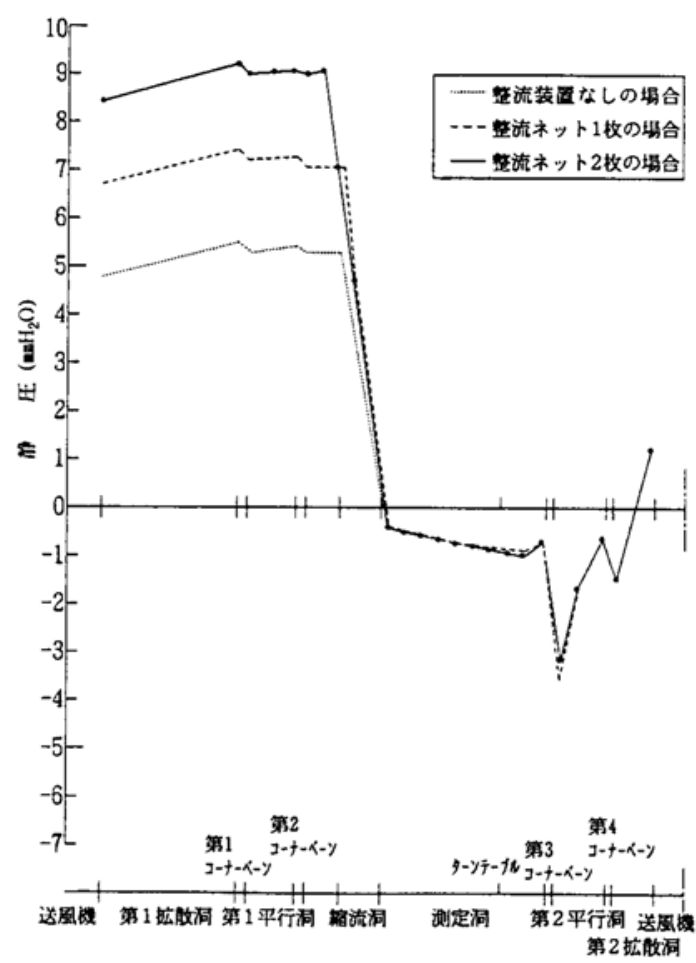

Fig. 3 静圧分布

(Distribution of static pressure along the wind tunnel)

た場合は, 整流装置を設けない場合より乱れの強さはわ ずかに減ずる程度であった。しかし, 整流ネットを2枚 設置すると, $5 \mathrm{~m} / \mathrm{s}$ 未満の低風速を除けば, 乱れの強さ は $1 \%$ 以下になり, 目標の性能をほぼ達成できた。また， 後述のように, この状態で, 風速分布はほぼ一様になっ ていることも確認できた。したがって, 本風洞は整流八 二カムの設置も可能な設計になっているが,この結果を 考慮して, 現在は八ニカムは設けず, 整流ネット2枚の みを設置した状態で稼働している。

\section{2 静圧分布}

静圧分布の測定結果をFig. 3に示した。これらは,い ずれも測定部での平均風速 $10 \mathrm{~m} / \mathrm{s} の$ 場合である。縮流洞 出口以降, 送風機までの間の静圧分布は 3 者ともほぼ同 様である。送風機〜縮流洞入口間では整流ネット1枚設 置するごとに約 $2 \mathrm{~mm} \mathrm{H}_{2} \mathrm{O}$ 程度の静圧上舁が生じている。 その他, 圧損の大きい部分は, 笔流洞を除けば, 飛散防 止ネットを取り付けた第3コーナベーンだけである。ま た，測定洞の風上端～風下端間では約 $0.5 \mathrm{~mm} \mathrm{H}_{2} \mathrm{O}$ の圧力 隇少が生じているが, 圧力係数に換算すると0.08であり， 余り大きくはない。

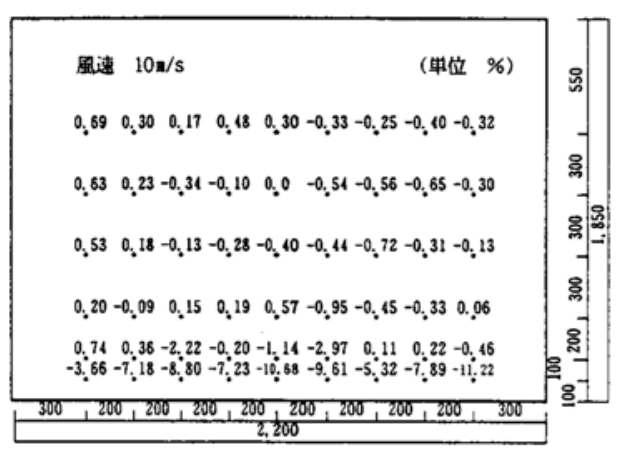

Fig. 4 ターンテーブル中央での風速分布（偏差\%)

[整流ネット2枚を設置した場合]

(Distribution of mean wind speed deviation at the working section)

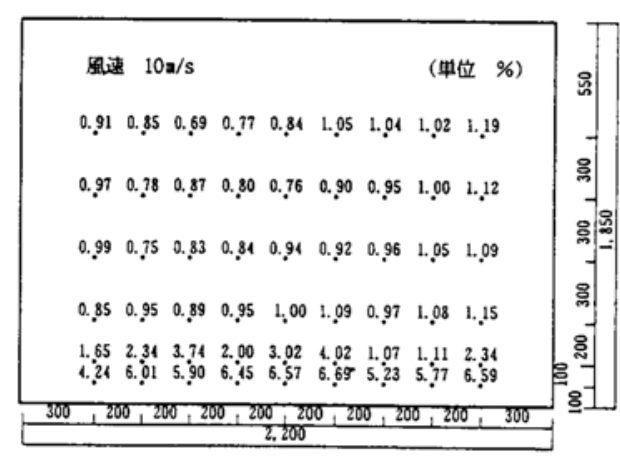

Fig. 5 ターンテーブル中央での乱れの強さの分布

[整流ネット2枚を設置した場合]

(Distribution of intensity of turbulence at the working section)

\section{3 風速および乱れの強さの分布}

ターンテーブル中央断面内での、断面中心の平均風速 に対する各点の平均風速の偏りおよび乱れの強さの分 布を, Fig. 4 およびFig. 5 に示した。平均風速の偏差 は風洞床近傍を除けば, ほぼ1\%以下である。乱れの強 さは測定部中心で約 $0.7 \%$, その他でも風洞床近傍を除 けば,ほぼ1\%程度または以下である。ともに当初目標 の性能が確保されている。なお, 床面および壁面の境界 層厚は約 $20 \mathrm{~cm}$ 程度である。

\section{4 振動}

風洞測定洞胴体の下地鉄骨フレーム材の中間に相当す る床仕上げ面および壁仕上げ面に小型加速度計を設定 し, 自由振動実験を行った結果, 風洞床面および壁面の 基本振動数はそれぞれ, $110 \sim 130 \mathrm{~Hz}, 80 \mathrm{~Hz}$ 前後であった。 したがって，それぞれ十分な剛性を有しており，また， ファンとの同調や床・壁の同調は生じないものと判断 される。

また, 風洞風速 $10 \mathrm{~m} / \mathrm{s}$ の場合, 測定洞胴体床面, 測定部 


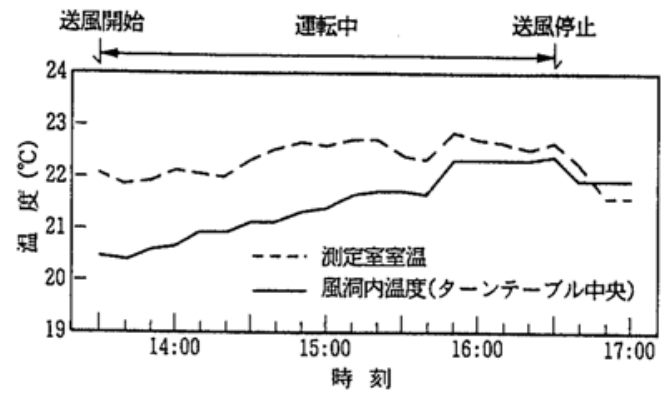

Fig. 6 風洞運転中の風洞内温度の変化

（風洞風速 $10 \mathrm{~m} / \mathrm{s}$ )

(Time variation of the temperature in the wind tunnel)

下部の地下ピットのコンクリート・ベース上, および, その上に設置した振動測定用マス (防振ゴム等, 未設置 の状態）上での上下方向最大加速度はそれぞれ2.9, 1.

4, 1. 1gal, 水平方向最大加速度はそれぞれ1. 5, 0.7, 0.8 galであった。この時, コンクリート・ベースおよび振 動測定用マス上での振動は, いくつかの振動数で小さな ピークを示す程度であり, 極めてランダムなものであっ た。

\section{5 風路内の温度変化}

風速を一定にして, ファンを継続的に運転して, その 間の風洞内部の温度变化を, 風洞外部の温度 (測定室室 温）とともに連続測定した結果をFig. 6に示した。風 洞内部の温度の測定位置は夕ーンテーブル中心とし, T 型熱電対を用いて測定した。Fig. 6は風速 $10 \mathrm{~m} / \mathrm{s}$ の場合 である。3時間の運転の間の温度上昇は, 測定室室温 0.

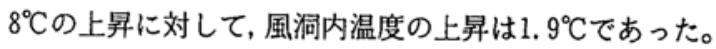
運転開始後, 風洞内温度は徐々に上昇した。その後, 風 洞内温度が測定室室温に近づくと, 風洞内温度は測定室 室温の変化に従うように変化しつつ, 測定室室温に近づ いている。このように, 風洞内温度の変化には, ファン の運転の影響によるものの他に, 測定室室温が影響して いる様子が分かり, 外気温の直接の影響は少ないことが 分かる。

\section{4. 実験気流の生成方法の検討 \\ 4. 1 境界層流れの生成方法}

境界層流れのシミュレーションには, 一般にスパイヤ やラフネス・ブロック等が用いられる。しかし, スパイ ヤのみでは, 厚い境界層の作成は可能であるが, 乱流特 性までを十分にシミュレートすることは難しいといわ れている。一方, ラフネス・ブロックのみでは, 乱流特 性はシミュレートできても, 十分な厚さの境界層を生成

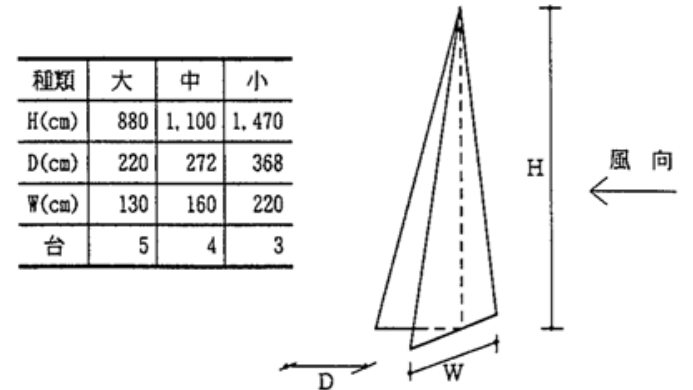

Fig. 7 スパイヤの形状

(Shape of the spires)

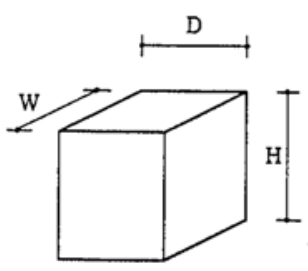

\begin{tabular}{c|c|c|c}
\hline 㮔類 & 大 & 中 & 小 \\
\hline$H(\mathrm{~mm})$ & 100 & 50 & 25 \\
$\mathrm{D}(\mathrm{mm})$ & 100 & 50 & 25 \\
$\mathbb{M}(\mathrm{mm})$ & 100 & 50 & 25 \\
\hline
\end{tabular}

Fig. 8 ラフネス・ブロックの形状

(Shape of the rougess blocks)

することは困難であるとされている。

したがって, 今回はスパイヤとラフネス・ブロックを 併用する方法によって、境界層流れを生成することを 検討した。

4. 2 スパイヤおよびラフネス・ブロックの試設計 風洞において境界層を再現する方法にはいまだルール は無いが, 一応の目安として, スパイアおよびラフネス・ ブロックの試設計を, H. P. A. H. Irwinの提案1)に基づい て行った。スパイアはFig. 7に示すょうな形状の「三 角スパイア」であり、考虑の対象はFig. 7 に示す 3 種 である。また, 考虑したラフネス・ブロックの大きさは Fig. 8に示した3とおりである。

目標とする境界層を, 日本建築学会建築物荷重指針 ・同解説の第6章「風荷重」で規定されている各地表面 粗度区分におけるものと考えた場合, 試設計の結果を記 すと以下のとおりである。なお, 文献 1) の方法で検討 できるのは, べき指数と境界層厚である。

・地表面粗度区分 II に対して, 縮尺率＝1/200はスパイヤ 大で, 狳尺率 $=1 / 300$ はスパイヤ中で, 樎尺率 $=1 / 400$ はスパイヤ小で, 所要の境界層 (べき指数と境界層厚) を実現できる。

・地表面粗度区分正に対して, 䑿尺率 $=1 / 200$ 境界層厚 は実現できない。縮尺率＝1/300はスパイヤ大, 縮尺率 $=1 / 400$ はスパイヤ中で, 縮尺率=1/500はスパイヤ小 で所要の境界層を実現できる。ラフネスは大, 中, 小 
Table 3 スパイヤとラフネス・ブロックの配置と境界 層作成結果

(Layout of roughness blocks and spires and the characteristics of the simulated wind)

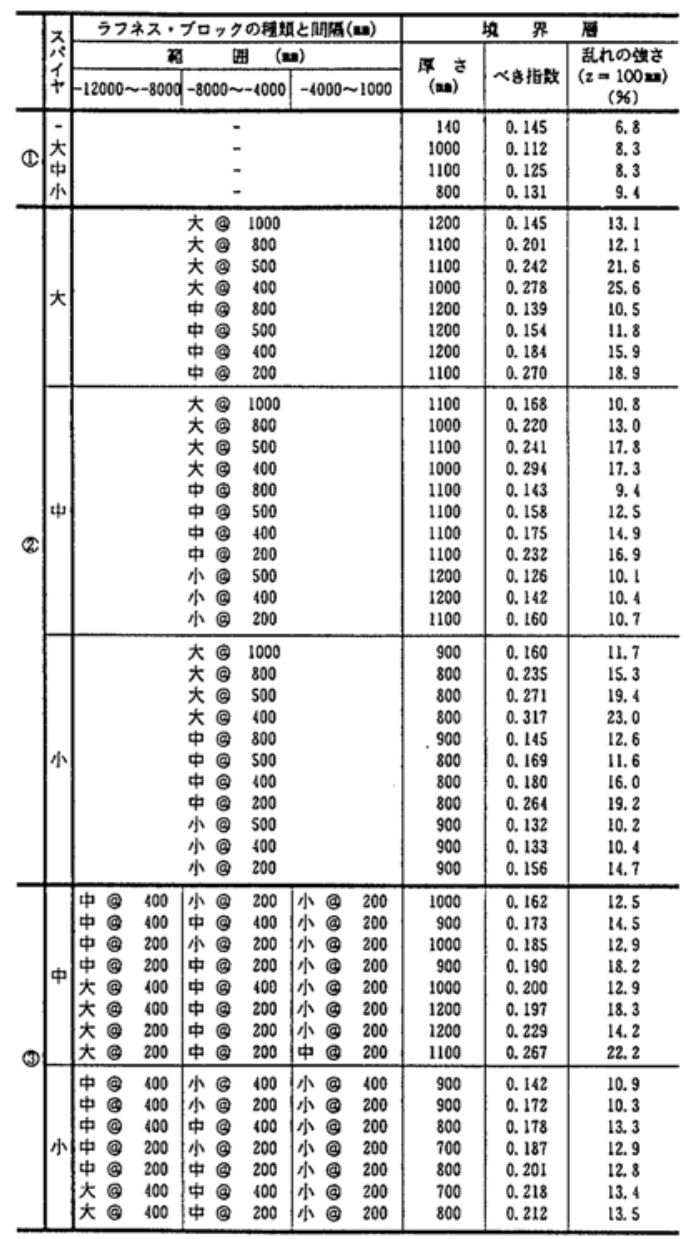

のいずれも利用できる。

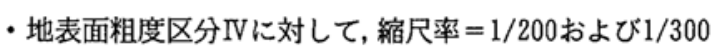
の境界層厚は実現できない。縮尺率 $=1 / 400$ はスパイ ヤ大で, 縮尺率 $=1 / 500$ はスパイヤ中で所要の境界層を 実現できる。ラフネスは大, 中のいずれかが利用でき る。

\section{3 境界層生成方法の検討方法}

スパイヤおよびラフネス・ブロックは各々, 上記の 3 種類を用いるものとして, 実際に境界層を生成し, 生成 された境界層の特性をチェックした。

この時, 次のような目的に従って, スパイヤとラフネ ス・ブロックの組合わせを考慮した。 (1)スパイヤの効果を明らかにするため, スパイヤのみを 用いた場合。

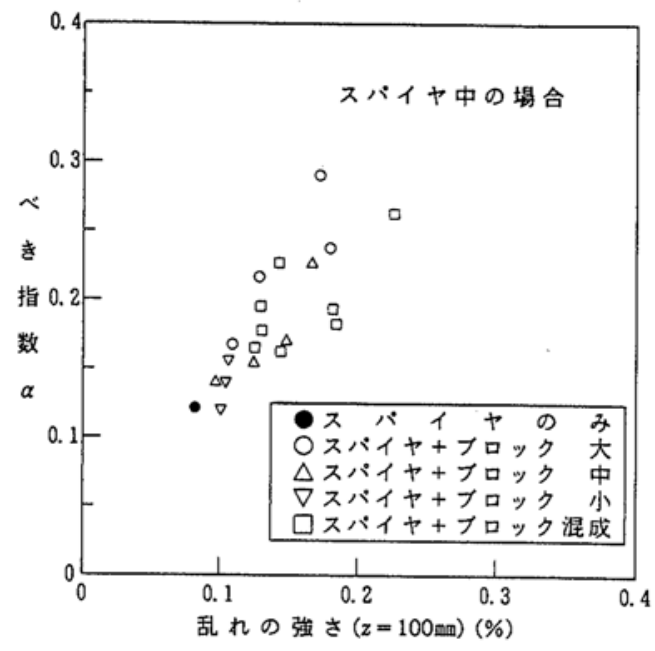

Fig. 9 乱れの強さとべき指数の関係

(Relation between the intensities of turbulence and the power-law indexes)

(2)ラフネス・ブロックの役割を明らかにするため, スパ イヤにラフネス 1 種類を組合わせた場合。

(3)所要の境界層への近似度を高めることを意図した場 合を想定して, スパイヤにラワネス複数種類を組合わ せた場合。

すなわち, Table 3に示すようなスパイヤおよびラフ ネス・ブロックの組合わせについて検討を行った。

\section{4 生成した境界層流れの特性}

生成した境界層流れの特性をTable 3中に示した。こ れより,以下のようなことが分かる。

(1)スパイヤの堵果について

スパイヤによって厚い境界層流れを作ることができる。 その厚さは, スパイヤ中, 小ではほぼスパイヤの高さに 等しい。しかし, 風速の雓直分布を表すべき指数 $\alpha$ は, 再現が必要と考えられる $\alpha=0.15 \sim 0.40$ に比べて, 0.11 〜0.13と小さい。また, 乱れの強さも10\%以下できわめ て小さい。

(2)ラフネス・ブロックの効果について

スパイヤにラフネス・ブロックを組合わせた場合, 境 界層厚の増加はほんの㒖かであり, 今回用いたサイズの ラフネス・ブロックでは境界層厚の増加には余り効果 はないことが分かる。

一方、ラフネス・ブロックを組合わせることによって, べき指数 $\alpha$ は增大し, ほぼ所要の值近くに達する。 $\alpha$ の 增大は大きなラフネスを用いた場合ほど著しく,ブロッ ク小で間隔 $500 \mathrm{~mm}$ 以ではほとんど増大しない。また、 乱れの強さも同様に增加する。Fig. 9 に床上 $100 \mathrm{~mm}$ に 


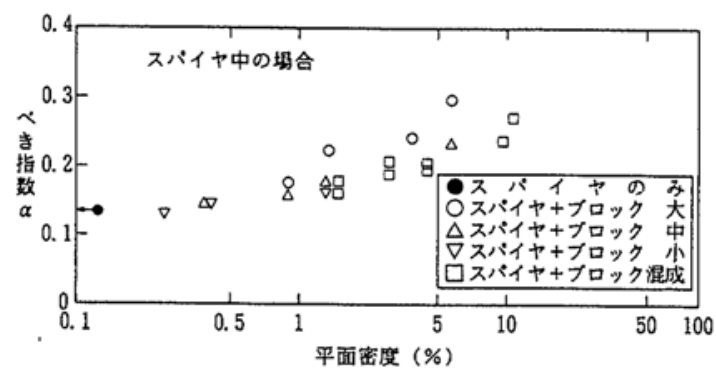

Fig. 10 平面密度とべき指数の関係

(Relation between the 2-dimensional densities of roughness block and the power-law indexes )

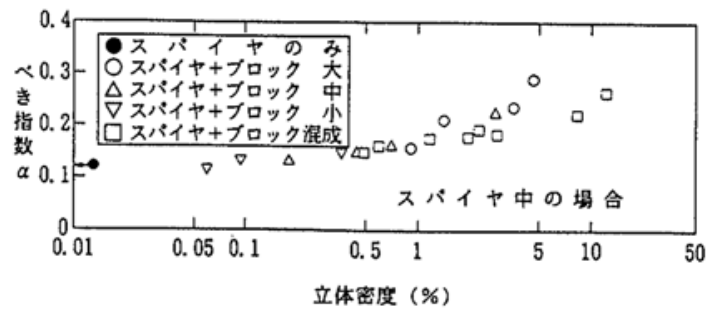

Fig. 11 平面密度とべき指数の関係

(Relation between the 3-dimensional densities of roughness block and the power-law indexes )

おける乱れの強さとべき指数の関係を示した。境界首 の縮尺を $1 / 300$ と考えると, 通常考元られている(1)式 の関係にほぼ対応していると見られる。

$$
\sigma_{\mathrm{V}} / \mathrm{V}(30)=\alpha
$$

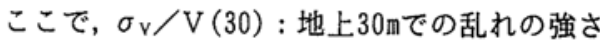
ただし、ブロック大の場合には, ブロック中、小に比べ て,べき指数が同じでも乱れの強さは若干, 小さい。 (3)所要の境界層および試設計との比較

上述した所要の境界層厚に対して, 地表面粗度区分吕, IVに対するものはほぼ実現できた。地表面粗度区分 II に対しては, 縮尺率の大きい場合は実現できた。しかし， 生成した境界㞒は上記の試設計よりも厚くなり, 今回用 いたサイズのスパイヤでは, より小さい縮尺率における 厚さの小さい境界層は再現できなかった。したがって, 用いるべきスパイヤは, 試設計より小さなサイズのもの とする必要があることが示唆された。 (4)複数種類のラフネス・ブロックを組合わせた場合に
ついて

Fig. 10 はラフネス・ブロックの平面密度とべき指数 の関係を, Fig. 11は立体密度とべき指数の関係を示し ている。立体密度は (2)式より求めたものである。 立体密度 $=$ 平面密度 $\times(\mathrm{H} / 10)$

ここで, $\mathrm{H}$ : ラフネス・ブロックの高さ $(\mathrm{cm})$ なお, 複数種類のラフネス・ブロックを用いた場合の密 度は, 流れ方向の平均值である。

複数種類のラフネス・ブロックを用いた場合でも, 立 体密度が等しければ, 1 種類のラフネス・ブロックを用 いた場合とほぼ同等のべき指数になっている。

また, 平面密度よりも立体密度の方がべき指数のばら つきが少なく,ラフネス・ブロックの効果は立体密度に よって評価できることが分かる。

\section{5. まとめ}

先程, 当社研究所内に新設された大型回流型境界層風 洞の概要と基本性能について記した。基本性能の調榃 により, 本風洞は建築用汎用風洞として十分な性能を有 していると判断できた。また, 建築関連の風洞実験に不 可欠な自然風の再現方法の検討結果についても記した。 境界層流れのシミュレーションにおけるスパイヤやラ フネス・ブロックの役割について考察ができ，また，ほ ぼ所要の境界首流れを再現できることが確認できた。

\section{謝辞}

本風洞の設計は当社建贸設計本部, 風洞装置の設計・ 製作は（株）都市環境リサーチによるものです。担当 されました各位およびご協力をいただきました関係各 位に対し，謝意を表します。

また, 風洞の企画当時, 快く風洞の見学をさせていた だき,有意義なアドバイスをいただきました, 多くの大 学や研究機関の方々に対して, 改めて, 御礼を申し上げ ます。

\section{参考文献}

1) H. P. A. H. Irwin; The Design of Spires for Wind Simulation, J. W. E. \& I. A., Vol.7, 1981, pp.361 - 366, 